\title{
Forest lands of industrial regions as an object of system monitoring and comprehensive assessment in modern conditions
}

\author{
T.A. Lebedeva, N.V. Grevtsev, L.N. Oleinikova, and A.A. Stikhin \\ Ural State Mining University, 620144, 30, Kuibyshev Str., Ekaterinburg, Russia
}

\begin{abstract}
The forest lands of industrial areas as an object of system monitoring and comprehensive assessment in modern conditions are represented in the form of natural objects, as a part of the ecological environment, as a subject of legal regulation of the land and forest relations.
\end{abstract}

\section{Introduction}

The forest lands are the "land plots suitable and intended for forestry, as well as occupied by the natural open stands and shrubs; they include the lands covered by the forest vegetation and the lands not covered by the forest vegetation (deforestation, burnt areas)" [1]. The forest lands are located on the lands of all (seven) land categories, but their main location is on the designated forest lands.

The industrial territories where there has been and is an increase in the production intensity through the more complete use of each natural-resources potential and space unit (all types of natural resources, the environment-forming role of ecosystems and their social functions).

Systematic monitoring of the forest lands is a part of environmental monitoring and represents a system of observations, assessments (mainly in physical measures) and forecasting aimed at obtaining the reliable information relating to the condition of forest lands, quantitative and qualitative specifications of its use.

The Forestry Code of the Russian Federation (2014) contains Article 53 "Fire hazard monitoring in forests" that considers the forest fire detection and recording system, forest development and decision-making system [3].

A comprehensive assessment of forest lands suggests determining the economic significance of the entire set of forest benefits: forest resources, environment-forming and social functions of the forests [4]. There are some (Federal Forestry Agency, Federal Land Inventory Service of Russia) methodologies for assessing the forests [5] and forest lands [6].

Modern conditions include the grand challenges [7], environmental risks [8] and economic and social uncertainties [9].

In our paper, the forest lands as an object of systematic monitoring and comprehensive assessment are considered from the following perspectives:

- as the natural objects 
- as a part of the economic domain

- as a subject of legal regulation of the land and forest relations

\section{Forest lands in the industrial regions as a natural object}

The representational scheme of the forest lands as an environmental object during the system monitoring and comprehensive assessment is shown in Fig. 1.

The forest lands as an object of the biosphere are part of the conveyor for the absorption of solar energy into the biomass matter with the participation of carbon dioxide and water. This process occurs in the green plants (mainly in the planted stands). A huge mass of living matter formed over billions of years on the planet during a long geological history, is located in the deposits and sedimentary strata. S.V. Belov, doctor of geological and mineralogical sciences [11], describes the circulation of elements in nature as following: "During lithogenesis, the sedimentary rocks sink into the depths of the Earth, and under the influence of pressure and temperature they turn into the magmatic deposits. Having cooled, they form the rock materials that are brought to the surface of the Earth, are destroyed and again generate the sedimentary strata containing organic matter". V.I. Vernadskiy argued [10]: "All the minerals in the Earth's upper crust, namely the free alumosilicic acids (clays), carbonates (limestones and dolomites), $\mathrm{Fe}$ and $\mathrm{Al}$ hydroxides (bog iron ores and bauxites) and many hundreds of other minerals are continuously created in it only under the influence of life".

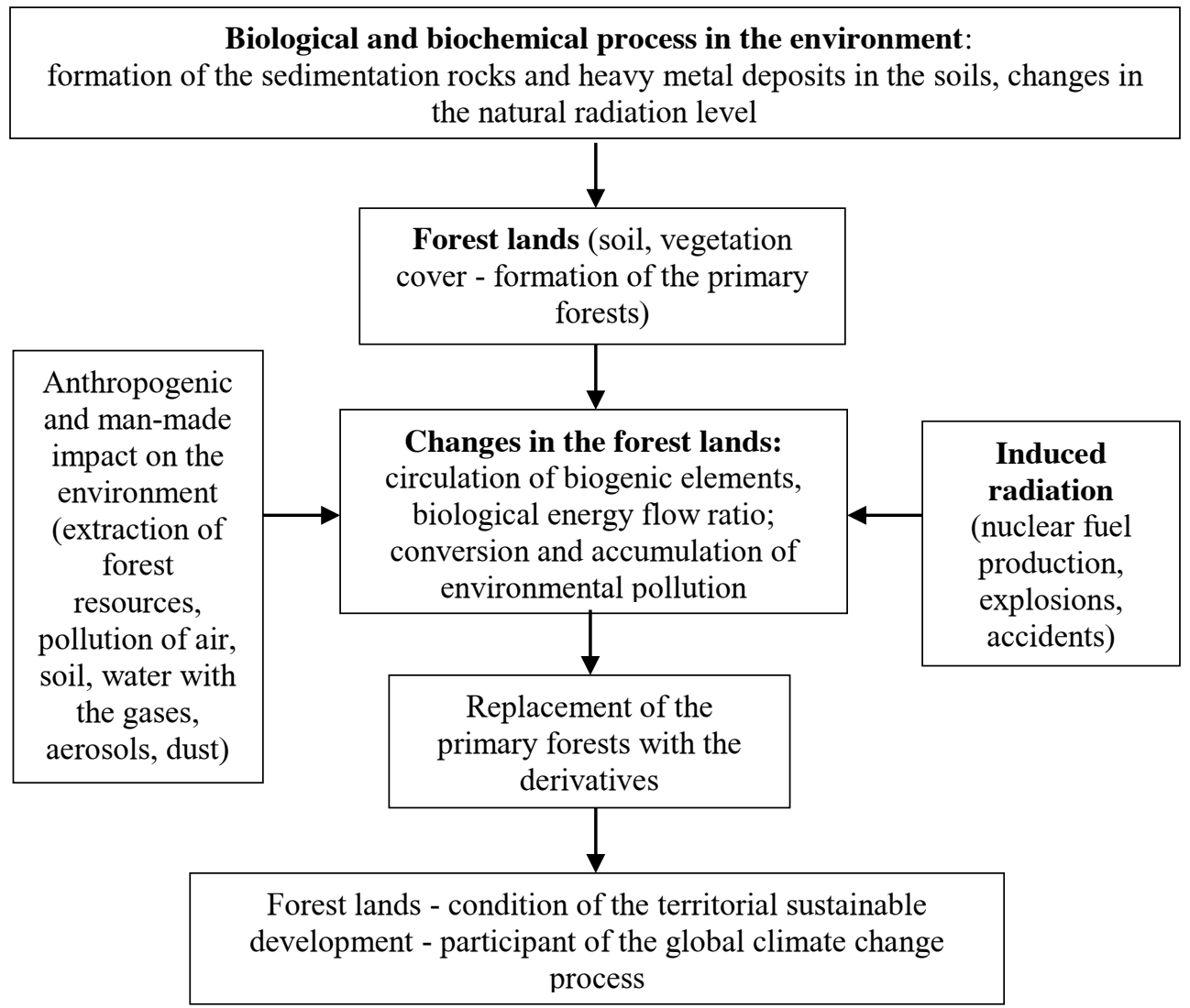

Fig.1. Representational scheme of the forest lands in the industrial regions during the system monitoring and comprehensive assessment as an environmental object 
From an environmental point of view, it is important to consider the ore deposits as the heavy metal carriers that are very toxic (which density is more than 8 thousand $\mathrm{kg} / \mathrm{m}^{3}: \mathrm{Pb}$, $\mathrm{Cu}, \mathrm{Zu}, \mathrm{Cd}$ etc.). In nature, there is a number of geochemical barriers that prevent the heavy metal dispersion as the toxic elements. The rock formations include the radioactive substances that emit ionizing radioactivity.

The rock formations have a significant impact on the forest soil formation and condition. An analysis of numerous publications related to the soil formation features in the forests of the Urals is given in the paper of G.G. Novogorodova [12]. It has been shown that "a significant meridional length of the Ural ridges crossing the natural zones from tundra to the semisavannas and semi-deserts determines the variety of conditions for the formation of mountainous and forest soils. It is complicated by the vertical zonality, heterogeneity, surface structure, expositional asymmetry of climate and vegetation, and variety of parent rocks materials".

The forest composition and distribution changed during the evolution of the Earth. In the course of palynological studies of vegetation dynamics in the Urals and Western Siberia, N.K. Panova [13] analyzed the papers related to the global dynamics of forest ecosystems and found out that the modern Russian forests were genetically related to the mode abundant forests of the Tertiary period. The climate of the Tertiary period that began about 67 million years ago demonstrated a rapid vegetation development. In the conditions of our temperate zone, the coniferous forests with the participation of heat-loving chestnut and beech forests predominated in the northern part. Due to the fall in temperature that began at the end of the Tertiary period (2.3-1.8 million years ago) and glaciation, the heatloving vegetation died, and the most cold-resistant species remained. After the glacial melting, the forests began to occupy the territories freed from ice. It is believed that the modern appearance of the Russian forests and forest lands has begun to take shape precisely during this period. The modern forest cover of the Urals and Western Siberia has historically been most closely related to the warming that began 1,500 years ago, when the forests and forest zone were formed within the borders close to the present ones.

When assessing the importance of forest soils, it must be borne in mind that the stocks of humus and various plant food elements have accumulated over millennia, and the individual tree species form the productivity of forest soils to varying degrees. The mild humus is formed by the birch, alder, larch, sometimes fir trees. The coarse humus is formed by spruce, pine, sometimes aspen.

During the process of the long-term economic activity in the Urals (up to 300 years) and in Western Siberia (more than 50-70 years), the forest lands and forests have undergone a 180-degree turn (its biological productivity has decreased) [14] and are continuing to change (the soils are polluted and the forest ecosystems are destroyed) [15]. The vegetation cover has been transformed (the native forest types are replaced by its derivatives), [16] the nature of the biogenic element cycle (mainly carbon) [17] in the forest ecosystems has been changed, the energy flow ration in the natural and anthropogenic environmental channels has been changed dramatically $[18,19]$. Up to $50 \%$ of pristine coniferous stands growing in the Urals in the past have been replaced by the nominally primary ones, and the remaining part has been replaced by the derivative hardwoods.

Over a long period of time (up to 300 years) the forest lands in the intensively developed territories of the Urals were subjected to a noticeable man-made impact (gases, aerosols, radiation).

Disturbance of the natural geochemical barriers during the metallic mining and subsequent ore processing lead to the heavy metal migration into the natural ecosystems.

The role of forests (forest lands) in global climate change on the planet is currently being actively studied and discussed. At the Paris summit in 2016, Article 5.1 of the Paris Agreement states: "The parties should take actions to protect and improve the quality of 
sinks and reservoirs of greenhouse gases... including the forests".

\section{Forest lands in the industrial regions as a part of the economic domain of society}

The representational scheme of the forest lands as a part of the economic domain of society during the system monitoring and comprehensive assessment is shown in Fig. 2.

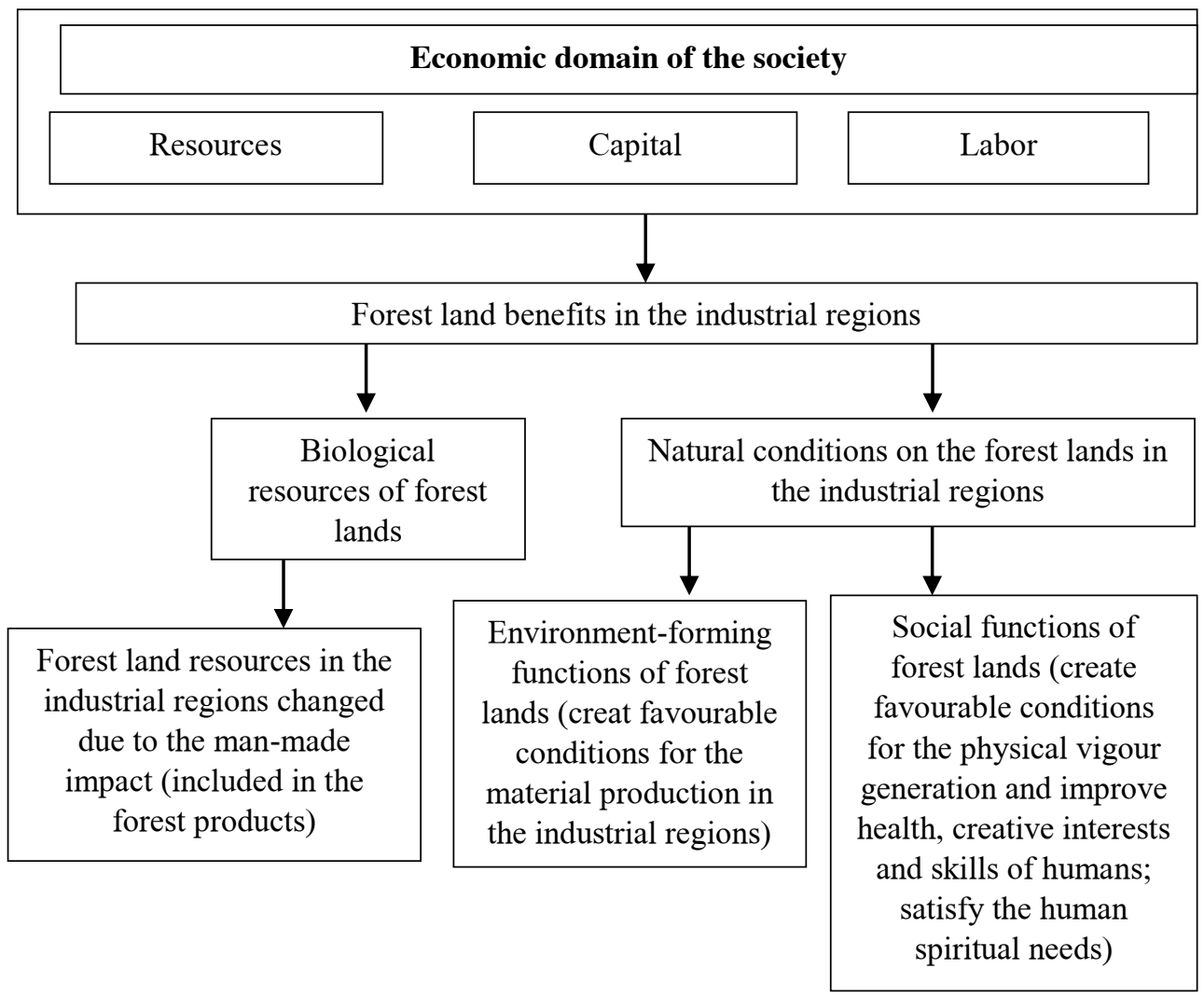

Fig. 2. Representational scheme of the forest lands as a part of the economic domain of society during the system monitoring and comprehensive assessment

The forest lands are considered in the form of natural ecosystems being the source of forest resources (materially included in the product composition), environment-forming functions (establish the favorable conditions for the life of all organisms and for material production) and social functions (recreation, health), implemented in the certain territories.

For about three centuries the forest lands of the Urals have been the center of mining and forestry, and now the forest land area is characterized by a high saturation of industrial production and population density. However, at the same time, the mountainous part of the Middle Urals also maintains the high percent forest cover, appearing against the background of the densely populated urbanized foothills as a real green island that has a huge climate control, water protection, soil protection, sanitary and hygienic and social significance. In Western Siberia (Khanty-Mansiisk Autonomous District-Yugra), more than 500 licensed oil and gas fields with a total area of up to $30 \%$ of the forestry fund (more than 16 million ha) are located on the designated forest lands. On these forest land plots, there is an operating well stock consisting of 90 thousand commercial wells. In addition, 
there are about 40 thousand mothballed wells.

Figure 3 provides a list of the main functions of the forest land ecological potential in the industrial regions, considered during the system monitoring and comprehensive assessment.

At present, the main trends in the economic use of forest lands are as follows:

- activation of their use in the short-term land management plans; including the transfer of designated forest lands to other land categories and to various types of uses in the intensively developed territories;

- actualization of the forest land environmental role in the territory development strategic plans.

\begin{tabular}{|c|}
\hline $\begin{array}{c}\text { Set of functions of the forest land ecological potential in the industrial } \\
\text { regions considered } \\
\text { during the system monitoring and comprehensive assessment }\end{array}$ \\
\hline Maintenance of the atmosphere air content (carbon dioxide, ionized \\
oxygen with phytoncides)
\end{tabular}

Fig. 3. A list of the main functions of the forest land ecological potential considered during the system monitoring and comprehensive assessment in the industrial regions

\section{Forest lands in the industrial regions as an object of legal regulation of the land and forest relations}

The legal system is a set of universally binding rules of conduct established by the state. The features of the modern system of land relations for the forest lands are as follows:

- its multi-purpose use (according to the Forest Code, there are up to 16 types);

- introduction of the types of forest use (forest lands) that are not directly related to the use of forest resources (subsurface management, etc.);

- lack of clear certainty in the economic assessment of the forest land plots.

Since not only the forest resources (as a part of the products), but also the environmentforming functions of forest lands are used to satisfy the social material needs, the legal regulation, first of all, should consider the forest resources and environment-forming forest functions in totality [4]; secondly, it should reflect the conservation of biological diversity (its genetic [20], generic [21,22] and ecosystem [23] levels) to ensure life in all its forms of manifestation. It is important to preserve the social functions of forest lands (recreational, health-promoting, teasing, educational, aesthetic and artistic) to meet the human spiritual needs, ensuring his existence as a biological species [10, 24, 25, 26].

From the perspective of legal regulation of the relations between the society and nature, a list of recorded and assessed forest benefits is determined.

The Federal Forestry Agency mainly considers the forest resource potential with the 
separate environment-forming functions. The inter-departmental relations (State Committee of Land Resources, National Environmental Protection Committee of the Russian Federation) pay attention to the relevant types of forest benefits. In our paper, during the systematic monitoring and comprehensive assessment of forest lands, the considered forest benefits on the forest lands are given in Table 1.

Table 1. The set of forest benefits $(+)$ considered when assessing the forest lands with various types of protection

\begin{tabular}{|c|c|c|c|c|c|c|c|}
\hline \multirow[b]{3}{*}{$\begin{array}{l}\text { Categories of forest } \\
\text { protection }\end{array}$} & \multirow{3}{*}{$\begin{array}{c}\text { Commercial } \\
\text { forest } \\
\text { benefits }\end{array}$} & \multicolumn{6}{|c|}{ Environment-forming functions } \\
\hline & & \multicolumn{4}{|c|}{ Environment protection } & \multirow[b]{2}{*}{$\begin{array}{c}\text { Resource } \\
\text { reservation }\end{array}$} & \multirow[b]{2}{*}{ Information } \\
\hline & & $\begin{array}{c}\text { Soil } \\
\text { protection }\end{array}$ & $\begin{array}{c}\text { Water } \\
\text { treatment }\end{array}$ & $\begin{array}{c}\text { Air- } \\
\text { purifying }\end{array}$ & \begin{tabular}{|} 
Protection \\
against \\
snowdrifts \\
and noise
\end{tabular} & & \\
\hline $\begin{array}{l}\text { Forestry part of the } \\
\text { green field forests }\end{array}$ & + & & & + & & & \\
\hline $\begin{array}{l}\text { Parklands of the green } \\
\text { field forests }\end{array}$ & + & & & & & & \\
\hline $\begin{array}{l}\text { Prohibited areas along } \\
\text { the banks of the rivers, } \\
\text { lakes, water storage } \\
\text { reservoirs and other }\end{array}$ & + & + & + & & & & \\
\hline $\begin{array}{l}\text { Prohibited forest } \\
\text { zones protecting the } \\
\text { spawning sites of the } \\
\text { valuable round fish }\end{array}$ & + & & + & & & + & \\
\hline Anti-erosion forests & + & + & + & & & & \\
\hline $\begin{array}{l}\text { Protective forest zones } \\
\text { along the federal and } \\
\text { republican railways } \\
\text { and motor roads }\end{array}$ & + & + & + & & & & \\
\hline $\begin{array}{l}\text { Forests of the first, } \\
\text { second and third zones } \\
\text { for the sanitary } \\
\text { protection of health } \\
\text { resorts }\end{array}$ & 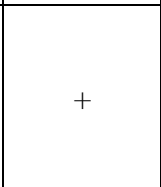 & & + & & & + & \\
\hline Highly valued forest & + & & & & & & \\
\hline $\begin{array}{l}\text { Forests having the } \\
\text { scientific or historical } \\
\text { value }\end{array}$ & + & + & & & & + & \\
\hline Natural landmarks & & & & & & + & + \\
\hline Nut harvesting zones & & & & & & & \\
\hline $\begin{array}{l}\text { Reserve forest areas, } \\
\text { conservation areas, } \\
\text { national parks }\end{array}$ & & & & & & & + \\
\hline Ribbon forests & + & & & & & & + \\
\hline Forests near the parks & + & & & & & + & \\
\hline $\begin{array}{l}\text { Other protective } \\
\text { forests }\end{array}$ & + & + & & & & + & + \\
\hline
\end{tabular}


Appendix to Table 1: The commercial forest lands include the forest resources and environmental functions, such as the carbon dioxide absorption, oxygen production, water conservation and water regulation, climate control and soil formation.

\section{Conclusion}

Thus, the forest lands as an object of system monitoring and comprehensive assessment in the industrial regions in modern conditions:

- are the products of biological and geochemical processes on the surface of our planet;

- are the basis for the formation of primary forests in the past that have the genetic memory relating to maintaining the conditions for sustainable development of the forest cover;

- at present, as a result of anthropogenic and man-made impacts, the forest lands represent the ecological systems of nominally primary and various derivative forest stands;

- in the industrial regions, the forest lands are the main accumulators and converters of the man-made environmental pollution;

- the forest lands are currently a necessary condition for the sustainable territorial development, the most important participant in the process of global climate change;

- the forest lands are a source of natural benefits: resources in the form of material objects, environment-forming functions that provide favorable conditions for biota and material production, and a social role that contributes to the satisfaction of spiritual and aesthetic needs;

- the forest lands are the object of legal regulation of the land and forest relations.

\section{References}

1. Encyclopedia of forestry: in 2 volumes. V.1, Moscow, All-Russian Research Institute of Silviculture and Forestry Mechanization, 426 (2006)

2. Yu.V. Lebedev, Ecologically sustainable development of the territories: the patriotic view of a Soviet person, 472 (Yekaterinburg, 2017)

3. Method of change remote control in the forest resources under the influence of oil and gas exploration and extraction (Moscow: USSR State Forestry Committee, 1990)

4. Yu.V. Lebedev, Assessment of forest ecosystems in the natural resource management system, 574 (Yekaterinburg: Ural Branch of the Russian Academy of Sciences, 2011)

5. Forest economic assessment methods. Order No. 43 dated March 10, 2000, 31 (Moscow: Federal Forestry Agency, 2000)

6. Methods of the state cadastral valuation of the designated forest areas of the Russian Federation. Approved by the Federal Land Inventory Service of Russia on April 15, 2002 No. ГT/263, 49

7. About the scientific and technological development strategy in the Russian Federation. Decree of the President of the Russian Federation No.642 dated December 1, 2016.

8. V.I. Osipov, V.M. Kutepov, V.L. Zverev et al., Dangerous exogenous processes, Ed. by V.I. Osipov, 290 (Moscow: GEOS, 1999)

9. V.P. Popov, I.V. Krainyuchenko, Theory and analysis of systems. Textbook, 245 (Pyatigorsk: Pyatigorsk State Technological University, 2012)

10. V.I. Vernadskiy, Chemical structure of the Earth biosphere and its environment, 376 (Moscow: Science, 1965)

11. S.V. Belov, Bulletin of natural resources, 12, 8 (2016)

12. G.G. Novogorodova, Forest formation process in the Urals and Trans-Urals, 50-68 (Yekaterinburg, 1996)

13. N.K. Panova, Forest formation process in the Urals and Trans-Urals, 26-49 
(Yekaterinburg, 1996)

14. R.P. Isaeva, K.I. Shakhova, Ways and methods of assessment of forest site capacity, 82-84 (Moscow, 1980)

15. Biological reclamation and monitoring of disturbed lands, 836 (Yekaterinburg, Ural State University, 2007)

16. E.P. Smolonogov, Forest formation process in the Urals and Trans-Urals, 4-25 (Yekaterinburg, 1996)

17. D.G. Zamolodchikov, Use and protection of natural resources of Russia, 1, 36-42 (2013)

18. V.G. Gorshkov, Botanical Journal, 65(11), 1579-1590 (1980)

19. P.M. Vitousek, P.R. Erlich, A.E. Erlich, P.A. Matso, Bioscience, 368-373, 1986

20. M.D. Golubovskiy, Chemistry and Life, 4, 36-42 (1997)

21. S.A. Mamaev, A.K. Makhnev, Forest assessment and rent: Book of reports, 80-83 (Yekaterinburg, 1996)

22. Yu.N. Isakov, Ecological and genetic variation and selection of Scots pine: Extended abstract of candidate thesis for Ph.D. in biological sciences, 36 (Saint-Petersburg, 1996)

23. Biological diversity of forest ecosystems, 365 (Moscow: International Forest Institute, 1995)

24. J. Yelinek, The large illustrated atlas of human, 559 (Prague: Artia. 1982)

25. I.G. Polyanskaya, V.V. Yurak, V.E. Strovsky, Economy of Region, 15(4), 1226-1240 (2019)

26. N.K. Roerich, Blessing ways, 800 (Moscow: Eksmo, 2004) 